\title{
PEST POPULATIONS DURING THE FIRST SIX YEARS IN RYEGRASS PASTURES CONTAINING WHITE OR CAUCASIAN CLOVER
}

\author{
R.N. WATSON, N.L. BELL, F.J. NEVILLE ${ }^{1}$ and L.T. DAVIS \\ AgResearch, Ruakura Agricultural Research Centre, Private Bag 3123, Hamilton \\ ${ }^{1}$ Deceased, 10 April 1999
}

\begin{abstract}
Insect and nematode pests in ryegrass pasture with white (WC) or Caucasian clover (CC) were similar in species composition. In droughtprone soil, however, WC abundance fluctuated markedly over six years whereas CC was more persistent. Insect pest populations in autumn followed similar overall time trends in each clover though some fluctuated less markedly in CC, probably due to greater clover abundance and pasture cover rather than food quality differences. Whitefringed weevil increased to damaging levels in $\mathrm{CC}$ by the sixth year. Clover cyst nematode populations were suppressed by CC but root knot nematode increased to greater abundance than in WC soil. Root knot nematode and whitefringed weevil may provide the greatest pest threats to longterm productive potential and persistence of $\mathrm{CC}$ in northern areas of New Zealand.
\end{abstract}

Keywords: Trifolium ambiguum, pests, Naupactus leucoloma, Heterodera trifolii, Meloidogyne hapla.

\section{INTRODUCTION}

Caucasian clover (Trifolium ambiguum) has shown promise as an alternative pasture legume to white clover (T. repens) with a wider range of climatic/edaphic tolerance provided partly by its rhizomatous habit. In a trial at Pongakawa in the Bay of Plenty, a ryegrass (RG; Lolium perenne)/CC dairy pasture established after maize cropping provided higher forage yields and/or legume content through spring to autumn during years 2-6 after establishment, compared with RG/WC pasture (Watson et al. $1996 \mathrm{a} ; 1997 ; 1998)$.

Insect and nematode pest populations monitored since pasture establishment provided, for the first time, the opportunity to determine if $\mathrm{CC}$ initiated different pest responses to those in RG/WC pasture and identify possible pest threats in advance of its wider adoption into pastoral farming. An early account of insect pests associated with the trial was reported by Watson et al. (1996b) and this paper summarises the information to date.

\section{METHODS}

The establishment and conduct of the trials has been described elsewhere (Watson et al. 1996a; 1997). Briefly, 0.125 hectare plots $\times 4$ replicates each of cv. Grasslands Kopu white clover and cv. Endura Caucasian clover were established as pure swards in September 1994 and undersown with cv. Yatsyn ryegrass in June 1995. The trial was sown on a Paengaroa sandy soil after 15 years maize cropping and the pasture was grazed by dairy cattle. Mown plots 5 x $5 \mathrm{~m}$, with and without nematicide treatment, were maintained as enclosures on each of the main plots and shifted biennially. In addition, herbage growth rates from grazed pasture have been determined from year 3. Agronomic results to year 5 are presented elsewhere (Watson et al. 1996a; 1997; 1998).

Soil insect pest populations were determined by soil sampling each autumn, with $100 \mathrm{~mm}$ diameter soil cores taken to $100-150 \mathrm{~mm}$ depth and sorted in the field. Damage 
by foliar feeding insects was assessed by scoring 30 clover leaves in pasture samples taken routinely from plots for herbage dissections. Soil nematode populations were sampled, usually seasonally, within each grazed plot using five $25 \mathrm{~mm}$ diameter cores stratified to 0-50 and 50-100 $\mathrm{mm}$ depth fractions and bulked. The nematodes were extracted from soil in Whitehead trays for two days, and the resulting elutriate settled in funnels overnight. Plant parasitic nematodes were identified from the whole sample and counted to genera under a microscope. Total nematodes, including non plantfeeding genera, were estimated in a Doncaster dish by counting $25 \%$ of the sample. Occasional nematode sampling was also conducted from the mown plots and this data was included with the accumulated nematode results. In May 1998 clover roots were washed from $10 \mathrm{~cm}$ diameter soil cores and stained in aniline blue to count nematodes within the roots. WC samples taken from within the $\mathrm{CC}$ plots were also included in root and foliar observations.

\section{Insect Pests}

\section{RESULTS AND DISCUSSION}

Grass grub (Costelytra zealandica) (GG) populations exceeded $50 / \mathrm{m}^{2}$ in the establishment year and peaked at $2-300 / \mathrm{m}^{2}$ during years 2 and 3 before declining in year 4 in association with severe drought conditions (Fig. 1). GG numbers initially increased more rapidly in WC, probably reflecting greater pasture growth and clover content in year 1 (Watson et al. 1996a), but also declined more rapidly in WC plots in year 4 . This related to the loss of clover cover and more extreme soil temperatures during summer drought (Watson et al. 1998). However, the decline in GG numbers continued in both pastures to year 6 . This completed an outbreak cycle typical of new pasture established after cropping and suggests that populations in both pasture types were ultimately regulated by disease build-up rather than pasture clover content. For example, milky disease (Bacillus popilliae) incidence of $15 \%$ was observed during grass grub sampling in February 1999 and can directly affect intergenerational survival in North Island grass grub populations (East and Wigley 1985; Miln 1982).
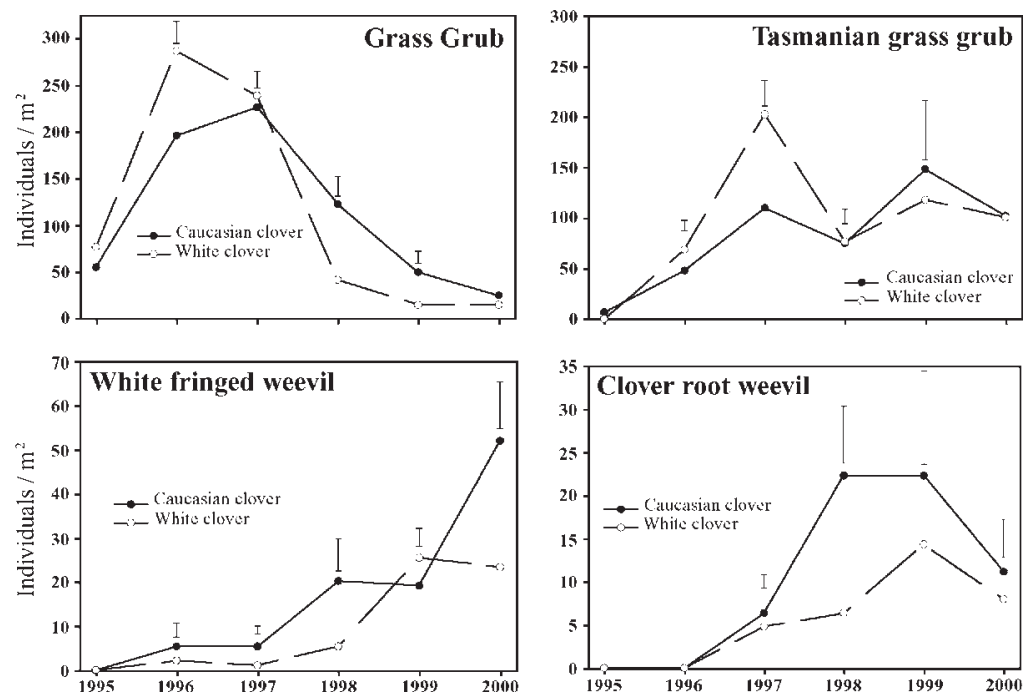

FIGURE 1: Grass grub, Tasmanian grass grub, whitefringed weevil and clover root weevil populations over six years in autumn from grazed ryegrass pasture with white or Caucasian clover. Vertical bars represent SEDs. 
Dymock et al. (1989) found no difference in food quality between the clovers for GG. Superficial scarring by GG feeding on CC taproot and rhizome surfaces was observed. This seldom lead to plant death, severance of rhizomes or secondary disease infection, but during peak populations the fibrous root system was markedly depleted by a combination of grass grub and root knot nematode (Watson et al. 1998.). The ability of CC to out-persist population outbreaks by grass grub following pasture establishment has also been observed in Canterbury (R. Arnst, pers. comm.)

Tasmanian grass grub (Aphodius tasmaniae) (TGG) numbers were initiated in CC plots in year 1 (Watson et al. 1996b), but increased more rapidly in WC to reach 100 and $200 / \mathrm{m}^{2}$ respectively in year 3 (Fig. 1). There was a decline in both populations in year 4 , but the overall trend was for a gradual increase in TGG numbers over six years. While 150 and 120 larvae $/ \mathrm{m}^{2}$ were recorded in CC and WC respectively under pasture in early May 1999, populations were highly aggregated under cow dung, where numbers approached $500 / \mathrm{m}^{2}$. These grubs may move out from dung to exploit pasture at a later stage. TGG is not directly dependent on clover for food. While leaves of both clover species were observed in the underground food stores, leaf material of other species was predominant. The TGG populations may have reflected other physical factors, such as a preference for open cover by adults during dispersal and oviposition in January.

Whitefringed weevil (Naupactus leucoloma) (WFW) populations recorded during autumn sampling were not high, and small sized larvae present at this time may have been underestimated from hand sorting. By late spring in the sixth year, the extensive $\mathrm{CC}$ rhizome network was observed to be breaking up into patches. Some rhizomes and taproots showed extensive feeding scars associated with large sized WFW larvae, which penetrated into the conductive tissues and severed some rhizomes. The breakup of CC may also have resulted from natural death of some of the original taproots, to which the developing rhizome network had hitherto maintained contact.

Clover root weevil (Sitona lepidus) (CRW) was first observed on this farm in 1996, and was expected to undergo a rapid population increase to damaging levels in white clover based on experience in Waikato pastures (Willoughby and Addison 1997; Addison et al. 1998). However, the intervention of successive summer droughts markedly suppressed the population increase (Fig. 1). Since CRW is directly dependent on clover, virtual disappearance of WC in year 4 accounted for particularly low numbers in May 1998. WC began recovering, largely from autumn and spring germinating seed in 1998, and achieved moderate levels by December 1999, before again suffering from drought. Adult weevil feeding notches on clover leaves indicated no strong preferences between $\mathrm{WC}$ and $\mathrm{CC}$ plots, or between clovers within the CC plots (data not presented). Foliar feeding by other insects (mostly Epyaxa rosearia on CC and Zizina labradus on WC) reflected that discussed by Watson et al. (1996b), but at reduced levels of damage.

The non-clover feeding black beetle (Heteronychus arator) maintained a similar presence in plots of either clover. Ryegrass pulling in late summer/autumn as a result of root pruning by the larval stage increased in 1999 and 2000, consistent with its pest status regionally.

\section{Nematode pests}

Counts of plant parasitic nematode species in the soil are presented on the basis of the proportion of the total plant parasite population (\% PP) present, taken over 32 sampling occasions from 1994 to 1999 and annualised to December. Non rootinvasive Paratrichodorus minor and Helicotylenchus labiatus were not affected by pasture type and predominated initially after maize cropping, at around 27 and $45 \%$ $\mathrm{PP}$ respectively. Populations of each nematode ultimately declined to around $10 \% \mathrm{PP}$ (Fig. 2). The clover root invading clover cyst (Heterodera trifolii) $(\mathrm{CCN})$ and root knot (Meloidogyne hapla) (RKN) nematodes were initially not detected. CCN in WC soil increased to a peak of $40 \% \mathrm{PP}$ in year 4 before declining to $<5 \%$ following the decimation of WC in summer 1997/98. In CC, CCN increased very slowly to a maximum $7 \%$ PP by 1997 . In contrast, RKN increased more rapidly in CC than in WC and stabilised at around 50\% PP by 1996. In WC RKN reached 30\% PP in 1996 before 

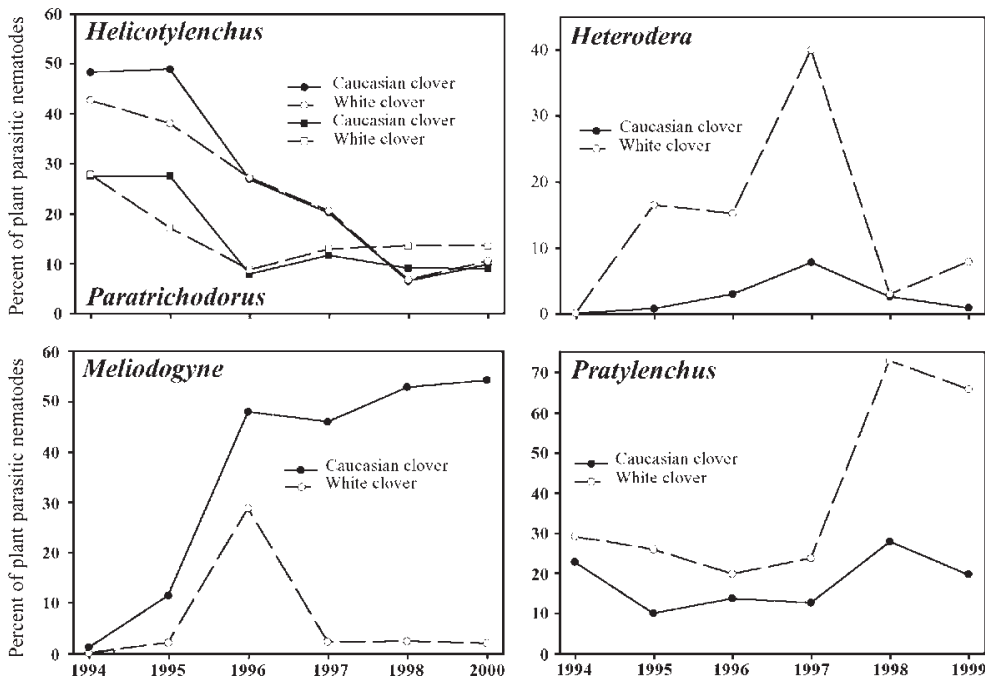

FIGURE 2: Relative soil populations over six years for Helicotylenchus, Paratrichodorus, Heterodera, Meloidogyne and Pratylenchus nematodes in ryegrass pasture containing white or Caucasian clover.

declining to only $2 \%$ subsequently. There was an increased response in pasture DM production to nematicide application in CC plots following the increase in RKN incidence (Watson et al. 1998). The remaining root-invading genus (lesion nematode, Pratylenchus spp.) has a wide host range including grass and weed species in addition to clover (Cook and Yeates 1993). Lesion nematode populations were maintained around $10-30 \%$ PP, but increased markedly to $72 \%$ in 1998 in the WC plots after the decline in $\mathrm{CCN}$. When the numbers of each nematode were accumulated for the 6 year sample period the ratios occurring in $\mathrm{CC}$ and WC soil respectively were 10:90 (CC:WC) for CCN, 79:21 for RKN and 21:79 for lesion nematode. CC is possibly a more favourable host for RKN than WC (Mercer and Millar 1997), but competition from CCN may have further contributed to its suppression in WC relative to CC. Lesion nematodes were apparently suppressed in the presence of CC even though it is regarded as a favourable host for one species present, $P$. penetrans (Thies et al. 1995). Nematodes in WC roots growing in association with CC tended to reflect levels present in $\mathrm{CC}$, with increased $\mathrm{RKN}$ and fewer $\mathrm{CCN}$ than in WC growing alone (data not shown). Populations of Paratylenchus nanus did not increase markedly from very low numbers at the start of the trial, despite being numerically dominant in adjacent long term pasture. Initially there were low populations of Macroposthonia sp. but this was not detected after three years in pasture.

\section{CONCLUSIONS}

Over six years $\mathrm{CC}$ showed greater persistence than $\mathrm{WC}$ in the face of climatic extremes. No pests were exclusive to the presence of either WC or CC. Small differences in some pest populations in some years may have related to transitory differences in overall clover abundance or to physical conditions within the pasture types. Two soil insects which reached economically damaging levels, TGG and black beetle, are not directly affected by the presence of clover as a food resource. Grass grub populations underwent a population outbreak cycle typical of new pasture, which was not prolonged significantly by the greater persistence of CC. Summer drought restricted the build-up to damaging levels of clover root weevil. Whitefringed weevil may have contributed to breaking up the rhizome network and a more patchy distribution of $\mathrm{CC}$ in the pasture by the sixth year. 
Clover feeding nematodes built up rapidly over the first three years of pasture after maize cropping. $\mathrm{CCN}$ was markedly suppressed in $\mathrm{CC}$ relative to $\mathrm{WC}$, but was compensated by a greater presence of RKN leading to an increased response to nematicide by year 4 . Nematodes were confirmed as playing a direct roll in white clover abundance, by exacerbating the effects of drought. When white clover declined to very low levels in pasture, clover nematode abundance was similarly reduced, thus facilitating vigorous seedling and stolon regeneration. The restricted distribution of root knot nematodes and clover feeding weevils in many South Island districts, and the suppression of clover cyst nematode, may enhance the opportunities for CC to significantly improve legume performance from pasture.

\section{ACKNOWLEDGEMENTS}

We wish to acknowledge the contributions made by our co-author, Frank Neville, over many years and in particular to this project, before he died tragically in a road accident. We again thank Catherine Cameron for biometrics services, Margaret and Rex Benner for their generous farm hosting, Kevin Garretty for stock management around our needs, Bill Webb (Agricultural Contractor) for agricultural services donated and Wrightson Research for supporting some data collection. This programme was also supported by the Foundation for Research, Science and Technology.

\section{REFERENCES}

Addison, P.J., Willoughby, B.E., Hardwick, S. and Gerard, P.J., 1998. Clover root weevil: observations on differences between 1997 and 1998 summer populations in the Waikato. Proc. 51st N.Z. Plant Prot. Conf:: 1-4.

Cook, R. and Yeates, G.W., 1993. Nematode pests of grassland and forage crops. Pp 305-350 In: Plant Parasitic Nematodes in Temperate Agriculture, K. Evans, D.L. Trudgill and J.M. Webster (Eds); CAB International, Wallingford, U.K.

Dymock, J.J., van den Bosch, J., Caradus, J.R. and Lane, G.A., 1989. Growth and survival of grass grub, Costelytra zealandica (White) (Coleoptera: Scarabeidae) on Trifolium species and T. repens x T. uniflorum hybrids. N.Z. J. Agric. Res. 32: 389-394.

East, R. and Wigley, P.J., 1985. Causes of grass grub (Costelytra zealandica (White)) population collapse in the northern North Island of New Zealand. Proc. 4th Australasian Conf. on Grassld. Invert. Ecol.: 191-200.

Mercer, C.F. and Miller, K.J., 1997. Evaluation of 15 Trifolium spp. and of Medicago sativa as hosts of four Meloidogyne species found in New Zealand. J. Nematol. 29 (4S): 673-676.

Milne, A., 1982. The role of disease in the population dynamics of grass grub (Costelytra zealandica White)). Proc. 3rd Australasian Conf. on Grassld. Invert. Ecol.: 147-154.

Thies, J.A., Petersen, A.D. and Barnes, D.K., 1995. Host suitability of forage grasses and legumes for root-lesion nematode Pratylenchus penetrans. Crop Sci. 35: 1647-1651.

Watson, R.N., Neville, F.J. and Bell, N.L., 1996b. Insect pests associated with white and Caucasian clover in a Bay of Plenty dairy pasture. Proc. 49th N.Z. Plant Prot. Conf: : 234-238.

Watson, R.N., Neville, F.J. and Bell, N.L., 1998. Caucasian clover performance in a year of severe drought. Proc. N.Z. Grassld. Assoc. 60: 119-125.

Watson, R.N., Harris, S.L., Neville, F.J. and Bell, N.L., 1996a. Caucasian clover as a pasture legume for dryland dairying in the coastal Bay of Plenty. Proc. N.Z. Grassld. Assoc. Conf. 58: 183-188.

Watson, R.N., Neville, F.J., Bell, N.L. and Harris, S.L., 1997. Caucasian clover for improving summer production in northern regions of New Zealand. Proc. N.Z. Grassld. Assoc. 59: 227-232.

Willoughby, B. and Addison, P.J., 1997. Clover root weevil (Sitona lepidus) - a threat to the sustainability of white clover in New Zealand pastoral systems? Pp 26-30 In: Soil Invertebrates in 1997, P.G. Allsop, D.J. Rogers and L.N. Robertson (Eds.); Bureau of Sugar Experimental Stations, Indooroopilly, Australia. 